Available online at Jurnal Metal Website: http:// https://journal.uhamka.ac.id/index.php/metalik

Metalik: Jurnal Manufaktur, Energi, Material Teknik

Jurnal Artikel

\title{
Pengaruh Sifat Konduktivitas Termal Material Isolator (Kayu, Karet Dan Styrofoam) Terhadap Perpindahan Panas Dan Daya Keluaran Sistem Generator Thermoelectric
}

\author{
Rifky $^{1 *}$, Vazri Muharom ${ }^{2}$ \\ ${ }^{1,2}$ Program Studi Teknik Mesin, Fakultas Teknik Universitas Muhammadiyah Prof. DR. HAMKA \\ ${ }^{1}$ rifky@uhamka.ac.id, ${ }^{2}$ vazrimuharom@gmail.com \\ *Corresponding author - Email: rifky@uhamka.ac.id
}

Artkel Info -: Received: 3 Dec 2021; Revised: 7 Jan 2022; Accepted: 10 Jan 2022

\begin{abstract}
Abstrak
Tujuan dari penelitian ini adalah untuk mendapatkan isolator dari ketiga bahan (kayu, karet dan styrofoam) yang akan menghasilkan isolator panas yang baik pada termoelektrik. Penelitian ini dilakukan di lantai terbuka Fakultas Teknik Universitas Muhammadiyah Prof. DR. HAMKA di Jakarta, Indonesia antara Maret-Oktober 2019 dengan menggunakan 3 termoelektrik. Harapan dari percobaan ini adalah untuk menghasilkan listrik yang paling banyak dari ketiga bahan tersebut

Kata kunci: panduan; tulisan; format; judul
\end{abstract}

\section{Abstract}

The purpose of this experiment is to get insulator from all three material (wood, rubber and styrofoam) which will produce a good heat insulator on thermoelectric. This research was conducted on the open floor at the Faculty of Engineering, University Muhammadiyah Prof. DR. HAMKA in Jakarta, Indonesia between March-October 2019 by using 3 thermoelectric. The hope of this experiment is to produce the most electricity from the three materials

Keywords: Thermal conductivity, Heat Tranfer, Isolator, Thermoelectric

(C) 2020 by authors. Lisensi Jurnal Metal : Manufaktur, Energi, Material Teknik, Uhamka, Jakarta. Artikel ini bersifat open access yang didistribusikan di bawah syarat dan ketentuan Creative Commons Attribution ( $\underline{\text { CC-BY }}$ ) license.

\section{BAB 1 PENDAHULUAN}

\subsection{Latar Belakang}

Dalam kehidupan sehari-hari tak pernah terlepas dari panas atau kalor. Setiap material memiliki sifat termal yang berbedabeda tergantung jenis material. Pada umumnya material yang dapat menghantarkan panas hanyalah logam, tetapi sebenarnya material non logam juga dapat menghantarkan panas meskipun nilai konduktivitasnya kecil.

Isolasi termal digunakan untuk mengurangi kerugian energi yang terlalu besar akibat perpindahan panas dari sistem ke lingkungan atau sebaliknya. Isolasi termal berkembang tidak hanya untuk menghindari kebocoran panas, tetapi digunakan untuk mengontrol temperatur. Fungsi isolasi termal sangat penting dalam penggunaan energi panas yang harus seefisiensi mungkin. Oleh karena itu diperlukan bahan isolasi termal yang memiliki konduktivitas termal material yang rendah (Ali \& Kurniawan, 2013).
Konduktivitas termal material merupakan besaran yang menyatakan kemampuan suatu material dalam menghantarkan panas. Nilai konduktivitas termal material suatu bahan tentunya berbeda-beda. Hubungan nilai konduktivitas termal material dengan kemampuan menghantarkan panas adalah sebanding. Artinya jika semakin besar konduktivitasnya, maka semakin besar juga kemampuan dalam menghantarkan panasnya (Mohammad Istajarul Alim, Dina Mardiana, Anita Dwi A, 2017).

Pentingnya nilai konduktivitas termal material adalah untuk menentukan jenis penghantar yaitu konduksi sebagai panas yang baik (konduktor) untuk konduktivitas termal yang besar, sedangkan penghantar panas yang kurang baik (isolator) untuk nilai konduktivitas termal yang kecil (Sulistiyawati Dewi K., Dina Mardiana, Anita Dwi A., 2014).

Berdasarkan uraian di atas, diantara material isolasi antara kayu, karet, dan styrofoam yang memiliki sifat konduktivitas 
termal material sebagai material isolasi, maka manakah yang tepat yang akan digunakan pada thermoelectric.

\subsection{Rumusan Masalah}

Berdasarkan latar belakang yang telah diuraikan, maka perumusan masalahnya adalah bagaimana mendapatkan material yang tepat dari ketiga material antara kayu, karet, dan styrofoam.

\subsection{Batasan Masalah}

Pembahasan terhadap masalah yang ada agar tidak meluas dan menyimpang dari tujuan, dalam penelitian ini membatasi masalahnya dengan ruang lingkup sebagai berikut:

1. Material isolator yang dipakai adalah kayu, karet dan styrofoam.

2. Jenis themoelectric model TEC1-12706.

3. Penelitian diruang terbuka dengan memanfaatkan panas matahari.

\subsection{Tujuan Penelitian}

Adapun tujuan dari penelitian ini adalah:

1. Untuk mengetahui pengaruh material isolator (kayu, karet dan styrofoam) terhadap perpindahan panas sistem thermoelectric.

2. Untuk mengetahui pengaruh material isolator (kayu, karet dan styrofoam) terhadap daya keluaran generator thermoelectric.

\subsection{Manfaat Penelitian}

Penelitian ini diharapkan mampu memberikan manfaat, diantaranya sebagai berikut:

1. Menambah pengetahuan tentang pemilihan materal isolator thermoelectric.

2. Menambah referensi tentang material isolator thermoelectric.

3. Digunakan sebagai salah satu alternatif bahan isolator thermoelectric.

\section{BAB 2 DASAR TEORI}

\subsection{Energi Surya}

Energi surya memiliki peranan yang sangat penting sebagai tujuan ekonomi, sosial, sektor pembangunan berkelanjutan, dan sebagai penunjang dalam kegiatan ekonomi tingkat nasional. Pertumbuhan ekonomi dan pertambahan penduduk yang semakin meningkat, tentu mendorong perkembangan energi terbarukan yaitu energi alternatif demi memenuhi kebutuhan energi yang terus meningkat. Dalam penggunaanya energi terbarukan biasanya digunakan untuk menggantikan energi fosil yang semakin menipis, contoh dari energi terbarukan seperti: biomassa, panas bumi, energi surya, energi air, dan energi angin (Hamdi, 2017).

Energi surya adalah energi yang berupa sinar dan panas dari matahari dengan cara di pancarkan dan energinya dapat di manfaatkan. Energi ini dapat di peroleh secara gratis sehingga menjadi keuntungan karena tersedia di alam. (Sabin, 2017).

Potensi energi surya yang cukup besar. untuk memanfaatkan potensi energi surya yang ada di Indonesia, ada dua jenis teknologi yang telah diterapkan, yaitu:
1. Teknologi energi fotovoltaik (PV) adalah teknologi yang memanfaatkan cahaya matahari yang mengkonveksikan menjadi energi listrik. Misalnya sistem panas surya pada solar sell. Sistem ini disebut dengan sistem fotovoltaik (PV).

2. Teknologi energi termal adalah pemanfaatan termal (panas) matahari yang baik secara langsung maupun tidak langsung. Pemanfaatan langsung dapat digunakan untuk mengeringkan hasil pertanian (perkebunan dan perikanan) sedangkan pemanfaatan tidak langsung diterapkan pada sistem thermoelectric generator, dari panas menjadi listrik.

\subsection{Thermoelectric}

Sistem thermoelectric adalah perangkat panas berstatus solid yang dapat mengubah panas langsung menjadi listrik atau mengubah daya listrik menjadi daya termal untuk pemanasan atau pendinginan (Rui \& de Oliveir, 2011).

Ada tiga efek yang dapat diamati ketika rangkaian termokopel dialiri arus listrik, yaitu Efek Seebeck, Efek Peltier dan Efek Tomson.

\subsubsection{Seebeck Effect}

Kondisi yang terjadi pada Termoelektrik adalah perbedaan suhu antara dua sambungan mengakibatkan tegangan listrik atau dalam kata lain yaitu efek Seebeck (Al-Fikri, 2016). Agar lebih jelasnya dapat melihat persamaan di bawah ini:

$$
\mathrm{V}=\alpha . \Delta . \mathrm{T}
$$

\subsubsection{Peltier Effect $s$}

Penemuanya menjelaskan bahwa ketika tegangan diberikan pada termokopel, maka fenomena akan timbul yaitu perbedaan suhu pada kedua sisinya. Teori ini disebut dengan nama Thermoelectric Coller (TEC) (Pepayosa, 2018). Persamaanya dapat dilihat di bawah ini:

$$
\mathrm{Q}=\alpha . \mathrm{I} . \mathrm{T}
$$

\subsubsection{Thomson Effect}

William Thomson adalah fisikawan asal Inggris. Pada tahun 1851 penemuanya menyatakan pada saat benda konduktor diberi arus listrik maka fenomena yang terjadi yaitu timbul perbedaan (gradien) temperatur sesuai dengan perpindahan panas yang disebut efek Thomson, (Pepayosa,2018)

$$
q=\mathrm{K} \Delta \mathrm{T}
$$

\subsubsection{Konduktivitas Thermoelectric (TE)}

Saat ini, bahan termoelectric yang umum adalah material keramik electrical insulator yang dipergunakan adalah Bismuth telluride $\left(\mathrm{Bi}_{2} \mathrm{Te}_{3}\right)$ and alloys. Berdasarkan spesifikasi TEC112706, total hambatan listrik adalah $1.0 \times 10^{-5} \Omega$, di mana koefisien seebeck adalah $185(\mathrm{~V} / \mathrm{K})$ dan konduktivitas termal TEC adalah 1,9 (W/m.K) (Zhou \& Chu-ping, 2015).

\subsection{Perpindahan Panas}

Perpindahan panas atau heat transfer, adalah fenomena alam yang kaitanya pada kalor yang mengalami perpindahan panas. Perpindahan panas tidak dapat diukur dan diamati secara langsung, tetapi pengaruhnya dapat diamati dan diukur (Afdhal Kurniawan Mainil, 2012). 
Proses perpindahan panas mengenal tiga cara perpindahan, yaitu: konduksi (hantaran), konveksi (aliran), radiasi (sinaran). Perpindahan panas konduksi adalah berperpindahan suatu energi dari bagian yang bersuhu tinggi ke bagian yang bersuhu rendah, interaksi ini terjadi didalam media diam (padat atau cair) dengan terdapat perbedaan temperatur atau temperatur gradien (Wibowo, 2008).

\subsubsection{Perpindahan Panas Konduksi}

Perpindahan panas secara konduksi terjadi pada benda yang memiliki gradien suhu, dimana perpindahan energi terjadi pada bagian bersuhu tinggi ke bagian bersuhu rendah (Firmansyah Burlian, 2014).

$$
q=-K A \frac{\Delta T}{\Delta x}
$$

\subsubsection{Perpindahan Panas Radiasi}

Berbeda dengan perpindahan panas secara konduksi dimana perpindahan energi terjadi melalui perantara, pada perpindahan secara radiasi dimana energi bergerak melalui media atau pada ruang hampa dan kemudian akan diserap oleh benda lain (Hariady \& Fauzie, 2014).

$$
q=\sigma A T_{a}^{4}
$$

Ketika energi radiasi menghantam permukaan material, sebagian dari radiasi dipantulkan, sebagian lagi diserap, dan sebagian ditransmisikan, seperti yang ditunjukkan pada persamaan (6). Dimana reflektivitas $\rho$ sebagai fraksi terefleksi, absorptivitas $\alpha$ ketika fraksi terserap, dan transmisivitas $\tau$ sebagai fraksi ditransmisikan. (J.P Holman, 2010)

$$
\rho+\alpha+\tau=1
$$

Tabel 2-1 Sudut Radiasi Matahari

\begin{tabular}{|l|c|c|c|}
\hline Sudut kejadian, $\theta$ & 0 & 30 & 45 \\
\hline Glass cover \\
\hline Absorptivitas $\alpha \%$ & 5 & 5 & 5 \\
\hline Tranmisivitas $\tau \%$ & 90 & 90 & 89 \\
\hline Reflektivitas $\rho \%$ & 5 & 5 & 6 \\
\hline
\end{tabular}

Sumber: (Belessiotis, Vassilis, Soteris Kalogirou, n.d.)

Kalor netto (bersih) yang dilepas dari suatu permukaan adalah selisih antara energi yang di pancarkan dan energi yang di serap (J.P Holman, 2010).

$$
q=A(e E b-\alpha \mathrm{G})
$$

Dalam riset ini energi diperoleh dari pancaran langsung matahari melalui pengukuran intensitas radiasi maka digunakan persamaan dibawah ini (Aby Elsa Putra, Rifky, 2018)

$$
q=\operatorname{leff}=\tau . \mathrm{A} . \mathrm{I}
$$

\subsection{Daya Keluaran}

Daya listrik atau electrical power adalah jumlah energi yang diserap atau dihasilkan dalam sebuah sirkuit/rangkain.

$$
\mathrm{P}=\mathrm{V} . \mathrm{A}
$$

Konduktivitas termal Material merupakan besaran yang menyatakan kemampuan suatu material dalam menghantarkan suatu panas. Nilai konduktivitas termal menunjukan seberapa cepat kalor mangalir dalam bahan tertentu (Wibowo, 2008).

\begin{tabular}{|c|c|c|c|c|c|}
\hline Bahan & Temperatur ${ }^{\circ} \mathrm{C}$ & $\begin{array}{c}k \\
\left(\mathrm{~W} / \mathrm{m} .{ }^{\circ} \mathrm{C}\right)\end{array}$ & $\begin{array}{c}\rho \\
\mathrm{kg} / \mathrm{m}^{3}\end{array}$ & $\begin{array}{c}\mathrm{c} \\
\mathrm{KJ} / \mathrm{kg} \cdot{ }^{\circ} \mathrm{C}\end{array}$ & $\begin{array}{c}\alpha \times 10 \\
\mathrm{~m}^{2} / \mathrm{s}\end{array}$ \\
\hline \multicolumn{6}{|c|}{ Logam } \\
\hline Aluminium & 30 & 204 & 2,707 & 0,896 & 8.418 \\
\hline \multicolumn{6}{|c|}{ Bukan Logam } \\
\hline Kaca & 20 & 0,78 & 2700 & 0.84 & 3.4 \\
\hline kayu (maple or oak) & 30 & 0,17 & 540 & 2.4 & 1.28 \\
\hline Karet & 30 & 0,15 & 1200 & 2.0 & 0.62 \\
\hline Styrofoam (Polystrene) & 30 & 0,14 & 1000 & 1.3 & 1.1 \\
\hline
\end{tabular}

Berdasarkan hal tersebut tentunya nilai konduktivitas termal pada berbagai material akan memiliki nilai yang berbedabeda. Untuk dapat membandingkannya antar berbagai material, dapat ditulis pada tabel 2.1

Tabel 2-2 Sifat termal berbagai bahan.

Sumber: (J.P Holman, 2010)

\subsection{Material Isolator}

Material yang dapat menghantarkan panas dengan baik disebut konduktor sedangkan yang kurang baik disebut isolator. Isolator adalah suatu zat atau bahan yang tidak bisa menghantarkan panas maupun listrik. Fungsi dari isolator sebagai penghambat arus listrik dan panas. Ada beberapa isolator yang dapat digunakan pada themoelectric, yaitu kayu, karet dan styrofoam.

\subsection{Resistensi Termal Dinding}

Resistensi adalah suatu ketahan material terhadap panas yang diterima.

$$
\mathrm{R}=\frac{\Delta \mathrm{x}}{K \cdot A}
$$

Resistensi termal itu berbanding lurus dengan ketebalan lapisan material dan berbanding terbalik dengan konduktivitasnya.

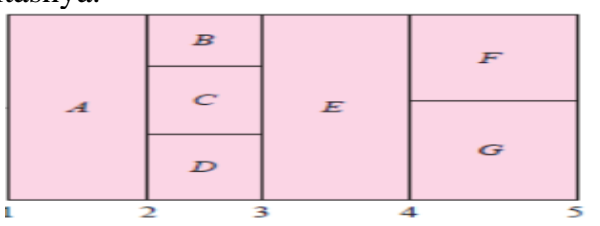

Gambar 2-4 Perpindahan panas seri dan paralel Sumber: (J.P Holman, 2010)

$$
\begin{aligned}
& \text { Rtotal }=R 1+R 2+\frac{R 3 * R 4}{R 3-R 4} \\
& q t=\frac{\Delta T}{\text { Rtotal }}
\end{aligned}
$$

\section{BAB 3 METODOLOGI}

\subsection{Tempat dan Waktu Penelitian}

Penelitian ini dilakukan di Fakultas Teknik Universitas Muhammadiyah Prof. DR. HAMKA Lt. 5 Jl. Tanah Merdeka No. 6, Pasar Rebo Jakarta Timur mulai bulan Maret s/d Oktober 2019.

\subsection{Desain Penelitian}

Desain penelitian yang digunakan dalam penelitian ini adalah penelitian eksperimental. Parameter yang digunakan 
adalah parameter perlakuan (treatment). Penelitian ini dilakukan dengan menggunakan alat simulasi seperti gambar 3-1

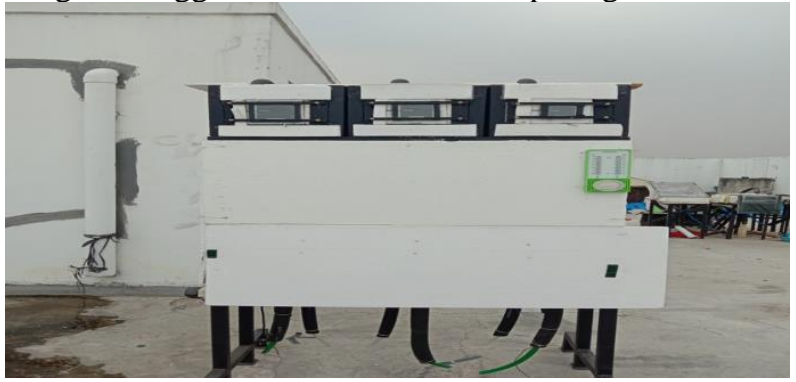

Gambar 3-1 Alat simulasi pengujian

Adapun contoh gambar pemasangan isolator pada sisi thermoelectric dapat dilihat pada gambar 3-2

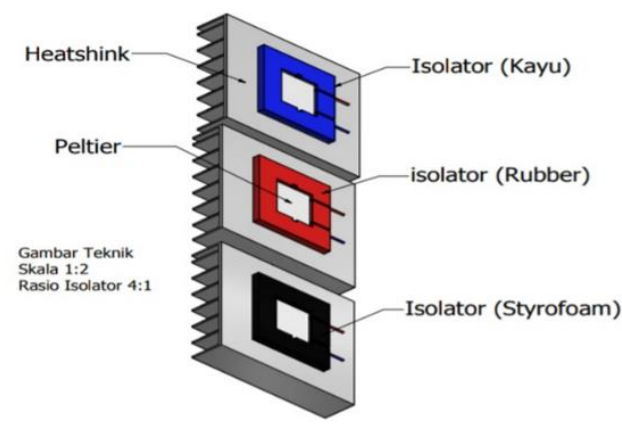

Gambar 3-2 Gambar contoh isolator

Selain itu contoh gambar skema sistem thermoelectric generator dapat dilihat pada gambar 3-3

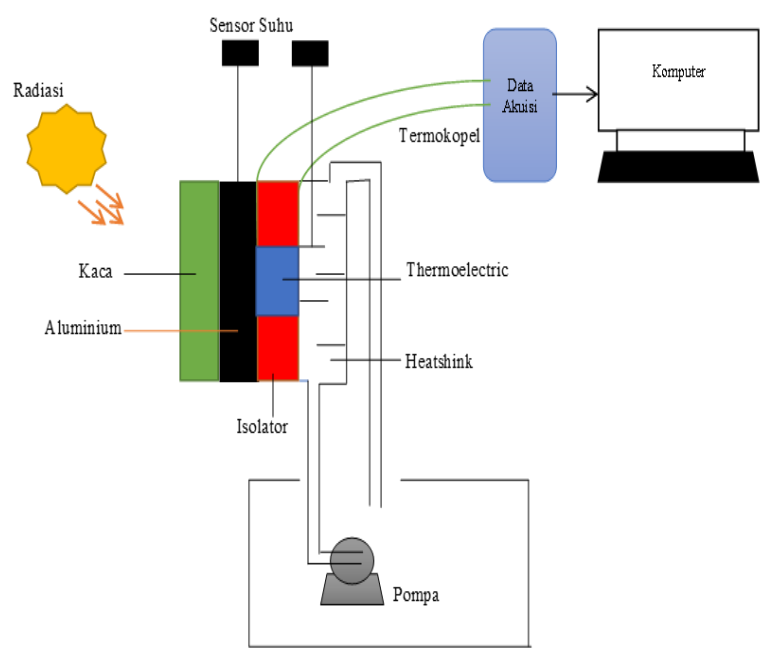

Gambar 3-3 Skema perangkat pengujian isolator

\subsection{Bahan dan Alat}

\subsubsection{Bahan Penelitian}

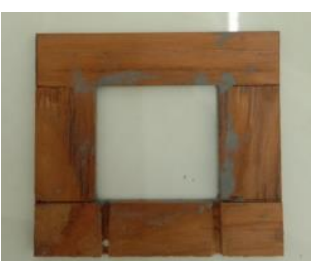

Spesifikasi

Material isolator : Kayu (Maple or oak)

Ukuran : P x L : 56,5 mm x 56,5 mm

Tebal : $4 \mathrm{~mm}$

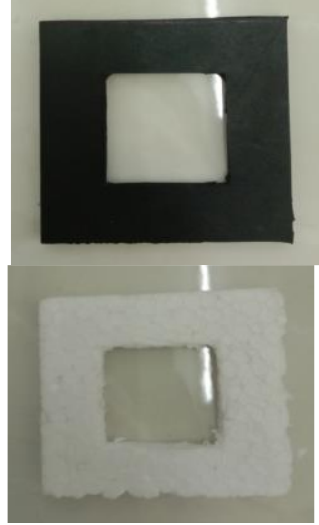

Spesifikasi

Material isolator : Karet (Rubber Sheet)

Ukuran : P x L : $56,5 \mathrm{~mm}$ x $56,5 \mathrm{~mm}$

Tebal : $4 \mathrm{~mm}$

\section{Spesifikasi}

Material isolator: Styrofoam (Polystrene)

Ukuran : P x L : 56,5 mm x 56,5 mm

Tebal : $4 \mathrm{~mm}$

\begin{tabular}{|c|l|l|}
\hline No & \multicolumn{1}{|c|}{ Nama Alat } & \multicolumn{1}{c|}{ Fungsi } \\
\hline 1 & ADAM 4018+ & $\begin{array}{l}\text { Berfungsi untuk akusisi } \\
\text { data temperatur pada } \\
\text { bagian material isolator } \\
\text { yang di input setiap satu } \\
\text { jam. }\end{array}$ \\
\hline 2 & Thermometer & $\begin{array}{l}\text { Berfungsi untuk } \\
\text { mengukur temperatur } \\
\text { pada bagian alumunium }\end{array}$ \\
\hline 3 & Solar power meter & $\begin{array}{l}\text { Berfungsi untuk } \\
\text { mengukur intensitas } \\
\text { matahari }\end{array}$ \\
\hline 4 & Power supply & $\begin{array}{l}\text { Dual volt amper meter } \\
\text { digital yang dapat di } \\
\text { gunakan untuk } \\
\text { mengukur arus (amper) } \\
\text { dan tegangan (volt) }\end{array}$ \\
\hline 5 & Anemometer & $\begin{array}{l}\text { Berfungsi untuk } \\
\text { mengukur kecepatan } \\
\text { angin yang melewati alat } \\
\text { uji. }\end{array}$ \\
\hline
\end{tabular}

\subsection{Metode Penelitian}

Diagram alir digunakan untuk mengetahui setiap kegiatan yang dilakukan dari awal sampai akhir penelitian. Berikut adalah diagram alir penelitian. 


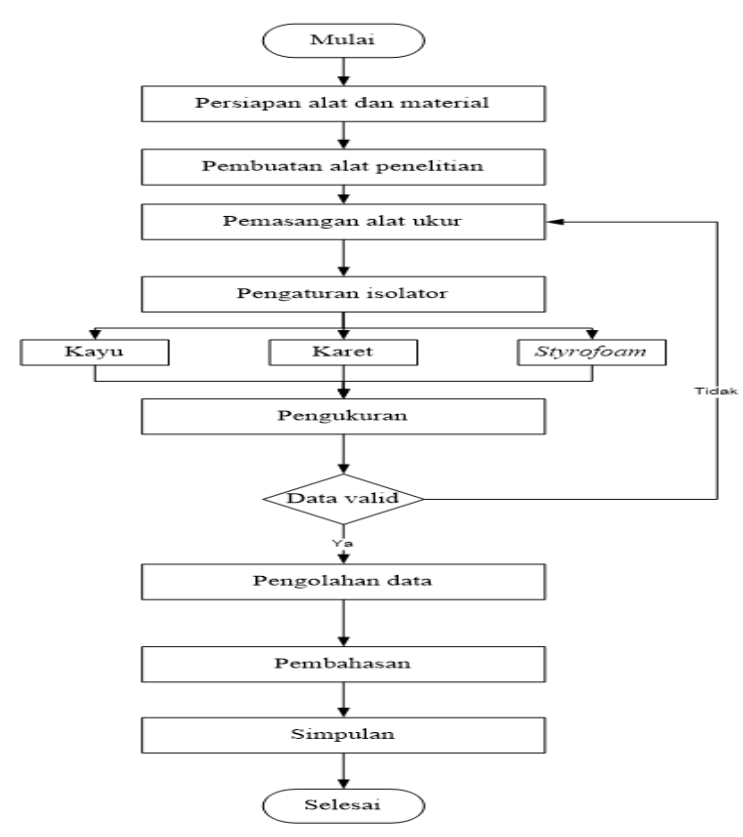

Gambar 3-12 Diagram alir penelitian

\subsection{Teknik Analisis Data}

Data yang didapatkan dari pengujian dihitung dan kemudian ditabulasikan setelah itu digambarkan dalam bentuk grafik, dari grafik yang didapat kemudian dijelaskan hasil pengujian tersebut.

\section{BAB 4 HASIL DAN PEMBAHASAN}

\subsection{Hasil Penelitian}

Hasil pengukuran dan pengamatan di dapatkan data mentah yang berupa nilai besarnya temperatur pada sistem thermoelectric dengan material isolator kayu, karet dan styrofoam dapat dilihat pada tabel berikut:

Tabel 4-2 Pengukuran isolator kayu

\begin{tabular}{|c|c|c|c|c|c|c|c|c|c|}
\hline No. & Pukul & $\mathrm{IV}[\mathrm{w} / \mathrm{m}]$ & $\mathrm{T}:\left[{ }^{\circ} \mathrm{C}\right]$ & $\mathrm{T} 2\left[^{\circ} \mathrm{C}\right]$ & $\mathrm{T} 3\left[{ }^{\circ} \mathrm{C}\right]$ & $\mathrm{T} 4\left[^{\circ} \mathrm{C}\right]$ & $\Delta \mathrm{T}{ }^{\circ} \mathrm{C}$ & Volt $(Y)$ & Amper (I) \\
\hline 1 & 07.00 & 735 & 33,4 & 37 & 35,2 & 27,6 & 5,8 & 0,01 & 0,01 \\
\hline 2 & 07.30 & 821 & 33,5 & 37,1 & 35,3 & 27,7 & 5,8 & 0,02 & 0,01 \\
\hline 3 & 08.00 & 861 & 33,6 & 37,2 & 35,4 & 27,8 & 5,8 & 0,03 & 0,01 \\
\hline 4 & 08.30 & 995 & 33,1 & 36,7 & 34,9 & 28,6 & 4,5 & 0,03 & 0,01 \\
\hline 5 & 09.00 & 1147 & 34,3 & 37,8 & 35,8 & 29,7 & 4,6 & 0,03 & 0,01 \\
\hline 6 & 09.30 & 1184 & 35,7 & 39,1 & 36,8 & 30,9 & 4,8 & 0,03 & 0,01 \\
\hline 7 & 10.00 & 1193 & 36 & 38,5 & 36,1 & 29,9 & 6,1 & 0,04 & 0,01 \\
\hline 8 & 10.30 & 1197 & 36,3 & 39,1 & 35,7 & 30,2 & 6,1 & 0,04 & 0,01 \\
\hline 9 & 11.00 & 1179 & 37,2 & 40 & 36,5 & 31,2 & 6 & 0,04 & 0,01 \\
\hline 10 & 11.30 & 1197 & 36,5 & 39,1 & 35,7 & 30,2 & 6,3 & 0,04 & 0,01 \\
\hline 11 & 12.00 & 1149 & 35,9 & 38,7 & 35,5 & 30,6 & 5,3 & 0,03 & 0,01 \\
\hline 12 & 12.30 & 1171 & 36,5 & 39,5 & 36,5 & 31,6 & 4,9 & 0,03 & 0,01 \\
\hline 13 & 13.00 & 1157 & 35,3 & 38,3 & 35 & 30,1 & 5,2 & 0,03 & 0,01 \\
\hline 14 & 13.30 & 1123 & 35,5 & 38,6 & 35,7 & 30,9 & 4,6 & 0,03 & 0,01 \\
\hline 15 & 14.00 & 1133 & 34,6 & 37,8 & 34,8 & 29,7 & 4,9 & 0,03 & 0,01 \\
\hline 16 & 14.30 & 1120 & 34,6 & 38 & 35,4 & 30,7 & 3,9 & 0,03 & 0,01 \\
\hline 17 & 15.00 & 950 & 33,8 & 37,3 & 34,7 & 30 & 3,8 & 0,03 & 0,01 \\
\hline 18 & 15.30 & 940 & 33,2 & 37,2 & 35 & 30,3 & 2,9 & 0,02 & 0,01 \\
\hline 19 & 16.00 & 890 & 32,5 & 36,4 & 33,8 & 29 & 3,5 & 0,02 & 0,01 \\
\hline 20 & 16.30 & 735 & 31,3 & 35,4 & 33,2 & 28,7 & 2,6 & 0,02 & 0,01 \\
\hline 21 & 17.00 & 467 & 30,8 & 35,5 & 33,5 & 29,4 & 1,4 & 0,01 & 0,01 \\
\hline
\end{tabular}

Tabel 4-3 Pengukuran isolator karet

\begin{tabular}{|c|c|c|c|c|c|c|c|c|c|}
\hline No. & Pulual & $\operatorname{IV}[\mathrm{wm}]$ & $\mathrm{T} 1\left[^{\circ} \mathrm{C}\right]$ & $\operatorname{T} 2\left[^{\circ} \mathrm{C}\right]$ & $\mathrm{T} 3\left[^{\circ} \mathrm{C}\right]$ & $\mathrm{T4}\left[^{\circ} \mathrm{C}\right]$ & $\Delta T^{\circ} \mathrm{C}$ & Volt (I) & Amper (I) \\
\hline 1 & 07.00 & 735 & 32,1 & 29,3 & 28,2 & 26,5 & 5,6 & 0,02 & 0,01 \\
\hline 2 & 07.30 & 821 & 32,2 & 29,4 & 28,3 & 26,6 & 5,6 & 0,03 & 0,01 \\
\hline 3 & 08.00 & 861 & 32,3 & 29,5 & 28,4 & 26,7 & 5,6 & 0,04 & 0,01 \\
\hline 4 & 08.30 & 995 & 31,7 & 29,1 & 28,6 & 27,6 & 4,1 & 0,04 & 0,01 \\
\hline 5 & 09.00 & 1147 & 33 & 30,3 & 29,7 & 28,7 & 4,3 & 0,04 & 0,01 \\
\hline 6 & 09.30 & 1184 & 34,3 & 31,4 & 30,8 & 29,7 & 4,6 & 0,04 & 0,01 \\
\hline 7 & 10.00 & 1199 & 34,4 & 28,7 & 28,6 & 28,3 & 6,1 & 0,05 & 0,01 \\
\hline 8 & 10.30 & 1197 & 34,6 & 32,6 & 31,3 & 28,6 & 6 & 0,04 & 0,01 \\
\hline 9 & 11.00 & 1179 & 35,7 & 31,7 & 31 & 29,5 & 6,2 & 0,05 & 0,01 \\
\hline 10 & 11.30 & 1197 & 34,7 & 30,6 & 29,8 & 28,4 & 6,3 & 0,05 & 0,01 \\
\hline 11 & 12.00 & 1149 & 34,2 & 30,6 & 29,9 & 28,6 & 5,6 & 0,05 & 0,01 \\
\hline 12 & 12.30 & 1171 & 35,2 & 31,5 & 30,8 & 29,6 & 5,6 & 0,04 & 0,01 \\
\hline 13 & 13.00 & 1157 & 33,7 & 30 & 29,2 & 28,1 & 5,6 & 0,04 & 0,01 \\
\hline 14 & 13.30 & 1123 & 34 & 30,6 & 30,1 & 28,9 & 5,1 & 0,04 & 0,01 \\
\hline 15 & 14.00 & 1193 & 33,2 & 29,8 & 29,1 & 28 & 5,2 & 0,04 & 0,01 \\
\hline 16 & 14.30 & 1120 & 33,2 & 30,4 & 29,9 & 28,8 & 4,4 & 0,04 & 0,01 \\
\hline 17 & 15.00 & 950 & 32,5 & 29,6 & 29,1 & 28 & 4,5 & 0,04 & 0,01 \\
\hline 18 & 15.30 & 940 & 32 & 29,8 & 29,5 & 28,6 & 3,4 & 0,03 & 0,01 \\
\hline 19 & 16.00 & 890 & 31 & 28,7 & 28,3 & 27,4 & 3,6 & 0,03 & 0,01 \\
\hline 20 & 16.30 & 735 & 30 & 27,9 & 27,8 & 27,1 & 2,9 & 0,02 & 0,01 \\
\hline 21 & 17.00 & 467 & 29,8 & 28.4 & 28,5 & 27,8 & 2 & 0,01 & 0,01 \\
\hline
\end{tabular}

Tabel 4-4 Pengukuran isolator styrofoam

\begin{tabular}{|c|c|c|c|c|c|c|c|c|c|}
\hline No. & Pukul & $\mathrm{IV}[\mathrm{wm} \mathrm{m}]$ & $\mathrm{T} 1\left[^{\circ \mathrm{C}}\right]$ & $\mathrm{T} 2\left[^{\circ} \mathrm{C}\right]$ & $\mathrm{T} 3\left[^{\circ} \mathrm{C}\right]$ & $\mathrm{T} 4\left[\left[^{\circ} \mathrm{C}\right]\right.$ & $\Delta \mathrm{T}{ }^{\circ} \mathrm{C}$ & Volt (V) & Amper (I) \\
\hline 1 & 07.00 & 735 & 30,9 & 36,8 & 34,5 & 26,9 & 4 & 0,02 & 0,01 \\
\hline 2 & 07.30 & 821 & 31 & 36,9 & 34,6 & 27 & 4 & 0,03 & 0,01 \\
\hline 3 & 08.00 & 861 & 31,1 & 37 & 34,7 & 27,1 & 4 & 0,04 & 0,01 \\
\hline 4 & 08.30 & 995 & 30,2 & 39,1 & 37,3 & 27,9 & 2,3 & 0,04 & 0,01 \\
\hline 5 & 09.00 & 1147 & 31,4 & $4 !$ & 36,7 & 28,9 & 2,5 & 0,05 & 0,01 \\
\hline 6 & 09.30 & 1184 & 32,6 & 42,6 & 38,3 & 29,9 & 2,7 & 0,05 & 0,01 \\
\hline 7 & 10.00 & 11993 & 32,7 & 44,2 & 35,3 & 28,5 & 4,2 & 0,06 & 0,01 \\
\hline 8 & 10.30 & 1197 & 33 & 42 & 36,1 & 28,8 & 4,2 & 0,06 & 0,01 \\
\hline 9 & 11.00 & 1179 & 33,8 & 42,8 & 41,5 & 29,9 & 3,9 & 0,06 & 0,01 \\
\hline 10 & 11.30 & 1197 & 33,2 & 42,2 & 36,1 & 28,7 & 4,5 & 0,06 & 0,01 \\
\hline 11 & 12.00 & 1149 & 32,8 & 42 & 38,8 & 29 & 3,8 & 0,05 & 0,01 \\
\hline 12 & 12.30 & 1171 & 32,5 & $41: 1$ & 38,1 & 29,9 & 2,6 & 0,05 & 0,01 \\
\hline 13 & 13.00 & 1157 & 32,3 & 38,1 & 41,6 & 28,5 & 3,8 & 0,05 & 0,01 \\
\hline 14 & 13.30 & 1123 & 32,6 & 41,9 & 40,9 & 29,4 & 3,2 & 0,05 & 0,01 \\
\hline 15 & 14.00 & 1133 & 31,7 & 38 & 41 & 28,4 & 3,3 & 0,05 & 0,01 \\
\hline 16 & 14.30 & 1120 & 31,9 & 37,4 & 38,5 & 29,3 & 2,6 & 0,05 & 0,01 \\
\hline 17 & 15.00 & 950 & 31,1 & 36,6 & 37,2 & 28,5 & 2,6 & 0,05 & 0,01 \\
\hline 18 & 15.30 & 940 & 30,8 & 37,5 & 35,8 & 29,2 & 1,6 & 0,04 & 0,01 \\
\hline 19 & 16.00 & 890 & 30 & 35,8 & 40,1 & 27,8 & 2,2 & 0,04 & 0,01 \\
\hline 20 & 16.30 & 735 & 28,9 & 37,1 & 39 & 27,6 & 1,3 & 0,03 & 0,01 \\
\hline 21 & 17.00 & 467 & 28,6 & 38,4 & 39 & 28,3 & 0,3 & 0,02 & 0,01 \\
\hline
\end{tabular}

\subsection{Pembahasan}

Pembahasan dibawah ini bertujuan untuk mengetahui pengaruh perpindahan panas paada thermoelectric dapat digambarkan susunan material yang terpasang pada alat simulasi seperti skema di bawah ini.

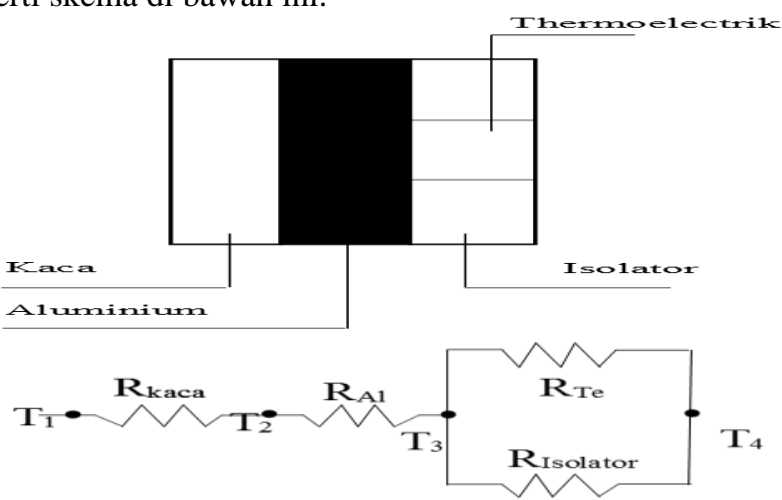

Gambar 4-1 perpindahan panas secara seri \& pararel 


\subsubsection{Perpindahan Panas Pada Thermoelectric}

Tabel 4-6 Hasil pengolahan data kayu

\begin{tabular}{|c|c|c|c|c|c|c|c|c|c|c|c|c|}
\hline No. & Puknl & $\operatorname{Ir}[\mathrm{wm}]$ & $\Delta T \mathrm{Ky}{ }^{\circ \mathrm{I}}$ & A Al $[\mathrm{m}]$ & t haca $[\%]$ & $\varphi[W]$ & R kara $[\mathrm{N}$ W & RAL $[\mathrm{KW}]$ & $\operatorname{RTe}[K / \mathbb{W}]$ & Ry $[\mathrm{KW}$. & $\begin{array}{l}\mathrm{R} \text { total } \\
{[\mathrm{KW}]}\end{array}$ & gt $[\mathbb{V}] \mathrm{ky}$ \\
\hline 1 & 07.00 & 735 & 5,8 & 0,00319 & 0.9 & 2,11167 & 4,01614 & 0,00614 & 1,282895 & \begin{tabular}{|l|l|}
14,41028 \\
\end{tabular} & 2,61401 & \begin{tabular}{|l|l}
2,21881 \\
\end{tabular} \\
\hline 2 & 07.30 & 821 & 5,8 & 0,00319 & 0.9 & 2,39875 & 4,01614 & 0,00614 & 1,282895 & 14,41028 & 2,61401 & 2,21881 \\
\hline 3 & 08.00 & 861 & 5,8 & 0,00319 & 0.9 & 2,47367 & 4,01614 & 0,00614 & 1,282895 & \begin{tabular}{|l|l|}
14,41028 \\
\end{tabular} & 2,61401 & 2,21881 \\
\hline 4 & 08.30 & 995 & 4,5 & 0,00319 & 0.9 & 2,88866 & 4,01614 & 0,00614 & 1,282895 & 14,41028 & 2,61401 & 1,72149 \\
\hline 5 & 09.00 & 1147 & 4,6 & 0,00319 & 0.9 & \begin{tabular}{|l|}
3,29536 \\
\end{tabular} & 4,01614 & 0,00614 & 1,282895 & \begin{tabular}{|l|l|}
14,41028 \\
\end{tabular} & 2,61401 & 1,75975 \\
\hline 6 & 09.30 & 1184 & 4,8 & 0,00319 & 0.9 & 3,40166 & 4,01614 & 0,00614 & 1,282895 & 14,41028 & 2,61401 & $\begin{array}{l}, 83626 \\
\end{array}$ \\
\hline 7 & 10.00 & 1193 & 6,1 & 0,00319 & 0,9 & 3,42752 & 4,01614 & 0,00614 & 1,282895 & 14,41028 & 2,61401 & 2,33358 \\
\hline 8 & 10.30 & 1197 & 6,1 & 0,00319 & 0.9 & 3,49901 & 4,01614 & 0,00614 & 1,282895 & \begin{tabular}{|l|l|l|l|} 
\\
\end{tabular} & 2,61401 & 2,33358 \\
\hline 9 & 11.00 & 1179 & 6 & 0,00319 & 0,9 & 3,38730 & 4,01614 & 0,00614 & 1,282895 & 14,41028 & 2,61401 & 2,29532 \\
\hline 10 & 11.30 & 1197 & 6,3 & 0,00319 & 0.9 & \begin{tabular}{|l|l|}
3,439001 \\
\end{tabular} & 4,01614 & 0,00614 & 1,282895 & \begin{tabular}{|l|l|}
14,41028 \\
\end{tabular} & 2,61401 & 2,41009 \\
\hline 11 & 12.00 & 1149 & 5,3 & 0,00319 & 0,9 & 3,30111 & 4,01614 & 0,00614 & 1,282895 & \begin{tabular}{|l|}
14,41028 \\
\end{tabular} & 2,61401 & 2,02754 \\
\hline .2 & 12.30 & 1171 & 4.9 & 0,00319 & 0.9 & 3,36431 & 4,01614 & 0,00614 & 1,282895 & 14,41028 & 2,61401 & 1,87451 \\
\hline 13 & 13.00 & 1157 & 5,2 & 0,00319 & 0,9 & 3,32409 & 4,01614 & 0,00614 & 1,282895 & \begin{tabular}{|l|l|}
14,41028 \\
\end{tabular} & 2,61401 & \begin{tabular}{|l|l|}
, 98928 \\
\end{tabular} \\
\hline 1.4 & 13.30 & 1123 & 4,6 & 0,00319 & 0.9 & 3,22641 & 4,01614 & 0,00614 & 1,282895 & \begin{tabular}{|l|l|l|l|l|} 
\\
\end{tabular} & 2,61401 & \begin{tabular}{|l}
1,75975 \\
\end{tabular} \\
\hline 15 & 14.00 & 1133 & 4,9 & 0,00319 & 0.9 & 3,25514 & 4,01614 & 0,00614 & 1,282895 & 14,41028 & 2,61401 & 1,87451 \\
\hline 16 & 14.30 & 1120 & 3,9 & 0,00319 & 0.9 & \begin{tabular}{|l|l|}
3,21779 \\
\end{tabular} & 4,01614 & 0,00614 & 1,282895 & \begin{tabular}{|l|l|}
14,41028 \\
\end{tabular} & 2,61401 & 1,49196 \\
\hline 17 & 15.00 & 950 & 3,8 & 0,00319 & 0.9 & 2,72937 & 4,01614 & 0,00614 & 1,282805 & 14,41028 & 2,61401 & 1,45370 \\
\hline 18 & 15.30 & 940 & 2,9 & 0,00319 & 0.9 & 2,70064 & 4,01614 & 0,00614 & 1,282895 & \begin{tabular}{|l|l|}
14,41028 \\
\end{tabular} & 2,61401 & 1,10941 \\
\hline 19 & 16.00 & 890 & 3,5 & 0,00319 & 0.9 & 2,55699 & 4,01614 & 0,00614 & 1,282895 & 14,41028 & 2,61401 & 1,33894 \\
\hline 20 & 16.30 & 735 & 2,6 & 0,00319 & 0,9 & 2,11167 & 4,01614 & 0,00614 & 1,282895 & 14,41028 & 2,61401 & 0,99464 \\
\hline 21 & 17.00 & 467 & 1,4 & 0,00319 & 0,9 & 1,34170 & 4,01614 & 0,00614 & 1,282895 & 14,41028 & 2,61401 & 0,53558 \\
\hline
\end{tabular}

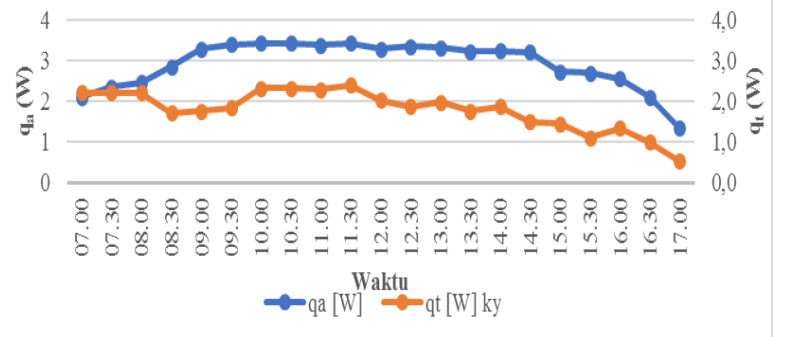

Gambar 4-2 Perpindahan panas isolator kayu

Tabel 4-7 Hasil pengolahan data karet

\begin{tabular}{|c|c|c|c|c|c|c|c|c|c|c|c|c|}
\hline No. & Pruku & $\mathrm{IV}[\mathrm{ym}$ ? & $\Delta \mathrm{T}$ tor $\mathrm{K}$ & AAl [m] & t thaca $[\%$ & $q 9[\mathrm{~W}]$ & R. kras [KI & {$[K W]$} & $\mathrm{P}$ & $R \operatorname{krt}[\mathrm{KW}]$ & $\begin{array}{l}\text { Rotoal } \\
{[\mathrm{KW}]}\end{array}$ & $\mathrm{qt}[\mathrm{W}] \mathrm{krt}$ \\
\hline 1 & 07.00 & 735 & 5,6 & \begin{tabular}{|l}
0,0319 \\
\end{tabular} & 0,9 & 2,11167 & 4,01614 & 0,00614 & 1,282895 & 16,33166 & 2,63002 & 2,12926 \\
\hline 2 & 07.30 & 821 & 5,6 & \begin{tabular}{|l|l|}
0,00319 \\
\end{tabular} & 0,9 & 2,35875 & 4,01614 & 0,00614 & 1,282895 & 16,33166 & 2,630022 & 2,12926 \\
\hline 3 & 08.00 & 861 & 5,6 & \begin{tabular}{|l|l|}
0,00319 \\
\end{tabular} & 0,9 & 2,47367 & 4,01614 & 0,00614 & \begin{tabular}{|l}
1,282895 \\
\end{tabular} & 16,33166 & 2,630022 & 2,12926 \\
\hline+ & 08.30 & 995 & 4,1 & 0,00319 & 0,9 & 2,85866 & 4,01614 & 0,00614 & 1,282895 & 16,33166 & 2,63002 & 1,55892 \\
\hline$i$ & 09.00 & 1147 & 4,3 & 0,00319 & 0,9 & 3,99536 & 4,01614 & 0,00614 & 1,282895 & 16,33166 & 2,63002 & \begin{tabular}{|l}
1,53497 \\
\end{tabular} \\
\hline 0 & 09.30 & 1184 & 4,6 & \begin{tabular}{|l|l|}
0,00319 \\
\end{tabular} & 0,9 & 3,40166 & 4,01614 & 0,00614 & 1,282895 & 16,33166 & 2,630022 & 1,74904 \\
\hline 7 & 10.00 & 1193 & 6,1 & 0,00319 & 0,9 & 3,42752 & 4,01614 & 0,00614 & 1,282895 & 16,33166 & 2,63002 & 2,31938 \\
\hline 8 & 10.30 & 1197 & 6 & \begin{tabular}{|l|l|}
0,0319 \\
\end{tabular} & 0,9 & 3,43901 & 4,01614 & 0,00614 & 1,282895 & 16,33166 & 2,63002 & 2,28135 \\
\hline 9 & 11.00 & 1179 & 6,2 & \begin{tabular}{|l|l}
0,0319 \\
\end{tabular} & 0,9 & 3,38730 & 4,01614 & 0,00614 & 1,282895 & 16,33166 & 2,630022 & 2,35740 \\
\hline 10 & 11.30 & 1197 & 6,3 & \begin{tabular}{|l|l|}
0,0319 \\
\end{tabular} & 0,9 & 3,449001 & 4,01614 & 0,00614 & \begin{tabular}{|l|l}
, 282895 \\
\end{tabular} & 16,333166 & 2,630022 & 2,39542 \\
\hline 11 & 12.00 & 1149 & 5,6 & 0,00319 & 0,9 & 3,30111 & 4,01614 & 0,00614 & 1,282895 & 10,33166 & 2,63002 & 2,12926 \\
\hline 12 & 12.30 & 1171 & 5,6 & 0,00319 & 0,9 & 3,36431 & 4,01614 & 0,00614 & 1,282895 & 16,33166 & 2,630022 & 2,12926 \\
\hline 13 & 13.00 & 1157 & 5,6 & $0,0,0319$ & 0,9 & 3,312409 & 4,01614 & 0,00614 & 1,282895 & 18,33166 & 2,630022 & 2,12926 \\
\hline 14 & 13.30 & 1.123 & 5,1 & 0,00319 & 0,9 & 3,22641 & 4,01614 & 0,00614 & 1,282895 & 16,33166 & 2,63002 & 1,93915 \\
\hline 15 & 14.00 & 1133 & 5,2 & 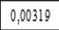 & 0,9 & 3,25514 & 4,01614 & 0,00614 & 1,282895 & 10,33166 & 2,630022 & 1,97717 \\
\hline 16 & 14.30 & 1120 & 4,4 & \begin{tabular}{|l|l|}
0,0319 \\
\end{tabular} & 0,9 & 3,21779 & 4,01614 & 0,00614 & 1,282895 & 16,33166 & 2,630022 & 1,67299 \\
\hline 17 & 15.00 & 950 & 4,5 & \begin{tabular}{|l}
0,00319 \\
\end{tabular} & 0,9 & 2,72937 & 4,01614 & 0,00614 & 1,282895 & 10,331666 & 2,630202 & 1,71101 \\
\hline 18 & 15.30 & 940 & 3,4 & \begin{tabular}{|l}
0,0319 \\
\end{tabular} & 0,9 & 2,70064 & 4,01614 & 0,00614 & 1,282895 & $10,3,33166$ & 2,630022 & \begin{tabular}{|l}
1,29277 \\
\end{tabular} \\
\hline 19 & 16.00 & 890 & 3,6 & 0,00319 & 0,9 & 2,55699 & 4,01614 & 0,00614 & 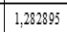 & 10,33166 & 2,63002 & 1,36881 \\
\hline 20 & 16.30 & 735 & 2,9 & 0,00319 & 0,9 & 2,11167 & 4,01614 & 0,00614 & 1,282895 & 16,33166 & 2,630022 & 1,10265 \\
\hline 21 & 17.00 & 487 & 2 & 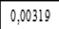 & 0,9 & 1,34170 & 4,01614 & 0,00614 & 1,282895 & 16,33166 & 2,630022 & 0,76045 \\
\hline
\end{tabular}

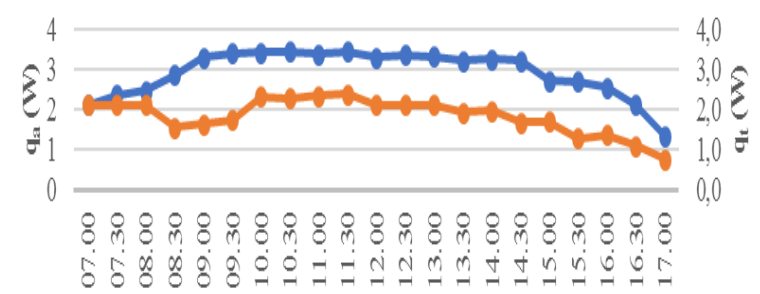

Waktu

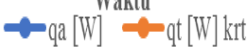

Gambar 4-3 Perpindahan panas isolator karet
Tabel 4-8 Hasil pengolahan data styrofoam

\begin{tabular}{|c|c|c|c|c|c|c|c|c|c|c|c|c|}
\hline & & & & & & & & & & & & \\
\hline No. & Pubal & $\operatorname{Iv}\left[\mathrm{w} / \mathrm{m}^{2}\right]$ & $\Delta \mathrm{T}_{\mathrm{sif}} \mathrm{K}$ & A A1 [ [n] & {$[$ theas $[\%]$} & $q_{2}[\mathrm{~W}]$ & $\mathbb{R}$ kace $[\mathrm{K} / \mathrm{N}]$ & $\mathbb{R} A L[K \mathbb{N}]$ & $\mathbb{R}_{\mathrm{e}}[\mathrm{KN}]$ & $\mathbb{R} \operatorname{stt}[K \mathrm{KW}]$ & $\begin{array}{l}\mathbb{R} \text { total } \\
{[\mathrm{K} W]}\end{array}$ & $\mathrm{qt}[\mathbb{W}]$ stf \\
\hline 1 & 07.00 & 735 & 4 & \begin{tabular}{|l|}
0,0319 \\
\end{tabular} & 0,9 & 2,11167 & 4,01614 & 0,00614 & 1,282895 & \begin{tabular}{|l|}
17,49821 \\
\end{tabular} & 2,63789 & 1,51637 \\
\hline 2 & 07.30 & 821 & 4 & 0,00319 & 0,9 & 2,35875 & 4,01614 & 0,00614 & 1,282895 & \begin{tabular}{|l|l|}
17,49821 \\
\end{tabular} & 2,63789 & 1,51637 \\
\hline 3 & 08.00 & 861 & 4 & 0,00319 & 0,9 & 2,47367 & 4,01614 & 0,00614 & 1,282895 & \begin{tabular}{|l|}
17,49821 \\
\end{tabular} & 2,63789 & 1,51637 \\
\hline 4 & 08.30 & 995 & 2,3 & \begin{tabular}{|l|}
0,0319 \\
\end{tabular} & 0,9 & 2,85866 & 4,01614 & 0,00614 & 1,282895 & 17,49821 & 2,63789 & 0,87191 \\
\hline 5 & 09.00 & 1147 & 2,5 & \begin{tabular}{|l|l|}
0,0319 \\
\end{tabular} & 0,9 & 3,29596 & 4,01614 & 0,00614 & 1,282895 & \begin{tabular}{|l|}
17,49821 \\
\end{tabular} & 2,63789 & 0,94773 \\
\hline 6 & 09.30 & 1184 & 2,7 & \begin{tabular}{|l|l|l|} 
\\
\end{tabular} & 0,9 & 3,40166 & 4,01614 & 0,00614 & 1,282895 & \begin{tabular}{|l|l|}
17,49821 \\
\end{tabular} & 2,63789 & 1,02355 \\
\hline 7 & 10.00 & 1193 & 4,2 & \begin{tabular}{|l|}
0,00319 \\
\end{tabular} & 0,9 & 3,42752 & 401614 & 0,00614 & 1,282895 & \begin{tabular}{|l|}
17498821 \\
\end{tabular} & 2,63789 & 1,59218 \\
\hline 8 & 10.30 & 1197 & 4,2 & \begin{tabular}{|l|l|}
0,0319 \\
\end{tabular} & 0,9 & 3,43901 & 4,01614 & 0,00614 & 1,282895 & \begin{tabular}{|l|}
1749821 \\
\end{tabular} & 2,67789 & 1,59218 \\
\hline 9 & 11.00 & 1179 & 3,9 & \begin{tabular}{|l|}
0,00319 \\
\end{tabular} & 0,9 & 3,38730 & 4,01614 & 0,00614 & 1,282895 & \begin{tabular}{|l|}
17,49821 \\
\end{tabular} & 2,63789 & 1,47846 \\
\hline 10 & 11.30 & 1197 & 4,5 & \begin{tabular}{|l|}
0,00319 \\
\end{tabular} & 0,9 & 3,49901 & 4,01614 & 0,00614 & 1,282895 & \begin{tabular}{|l|}
17,49821 \\
\end{tabular} & 2,63789 & 1,70591 \\
\hline 11 & 12.00 & 1149 & 3,8 & 0,00319 & 0,9 & 3,30111 & 4,01614 & 0,00614 & 1,282895 & \begin{tabular}{|l|}
17,49821 \\
\end{tabular} & 2,63789 & 1,4055 \\
\hline 12 & 12.30 & 1177 & 2,6 & 0,00319 & 0,9 & 3,36411 & 4,01614 & 0,00614 & 1,282895 & \begin{tabular}{|l|}
17,49821 \\
\end{tabular} & 2,67789 & 0,98564 \\
\hline 13 & 13.00 & 1157 & 3,8 & $\begin{array}{l}0,00319 \\
\end{array}$ & 0,9 & 3,32409 & 4,01614 & 0,00614 & 1,282895 & \begin{tabular}{|l|}
17,49821 \\
\end{tabular} & 2,63789 & 1,40055 \\
\hline 14 & 13.30 & 1123 & 3,2 & 0,00319 & 0,9 & 3,26641 & 4,01614 & 0,00614 & 1,282895 & \begin{tabular}{|l|}
17,49821 \\
\end{tabular} & 2,63789 & 1,213199 \\
\hline 15 & 14.00 & 1139 & 3,3 & 0,00319 & 0,9 & 3,25514 & 4,01614 & 0,00614 & 1,282895 & \begin{tabular}{|l|l|}
17,49821 \\
\end{tabular} & 2,63789 & 1,25100 \\
\hline 16 & 14.30 & 1120 & 2,6 & 0,00319 & 0,9 & 3,11779 & 4,01614 & 0,00614 & 1,282895 & \begin{tabular}{|l|}
1749821 \\
\end{tabular} & 2,63789 & 0,98554 \\
\hline 17 & 15.00 & 950 & 2,6 & 0,00319 & 0,9 & 2,72997 & 4,01614 & 0,00614 & 1,282895 & \begin{tabular}{|l|}
17,49821 \\
\end{tabular} & 2,63789 & 0,98554 \\
\hline 18 & 15.30 & 940 & 1,6 & 0,00319 & 0,9 & 2,70064 & 4,01614 & 0,00614 & 1,282895 & 17,49821 & 2,63789 & 0,60655 \\
\hline 19 & 16.00 & 890 & 2,2 & 0,00319 & 0,9 & 2,56699 & 4,01614 & 0,00614 & 1,282895 & 177,49821 & 2,63789 & 0,83400 \\
\hline 20 & 16.30 & 735 & 1,3 & 0,00319 & 0,9 & 2,11167 & 4,01614 & 0,00614 & 1,282895 & \begin{tabular}{|l|}
17,49821 \\
\end{tabular} & 2,63789 & 0,49282 \\
\hline 21 & 17.00 & 467 & 0,3 & 0,00319 & 0,9 & 1,34170 & 4,01614 & 0,00614 & 1,282895 & 17798821 & 2,63789 & 0,11373 \\
\hline
\end{tabular}

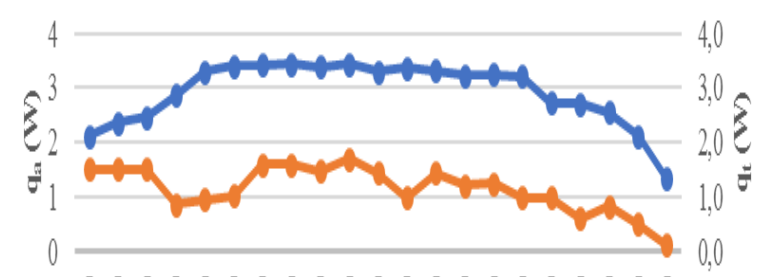

8080808808080080808

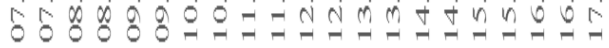

Walitu $\rightarrow$ gt $[\mathrm{W}] \mathrm{sff}$

Gambar 4-4 Perpindahan panas isolator styrofoam

Proses perpindahan panas untuk ketiga isolator pada sistem thermoelectric, dibandingkan satu sama lain menggunakan grafik berikut.

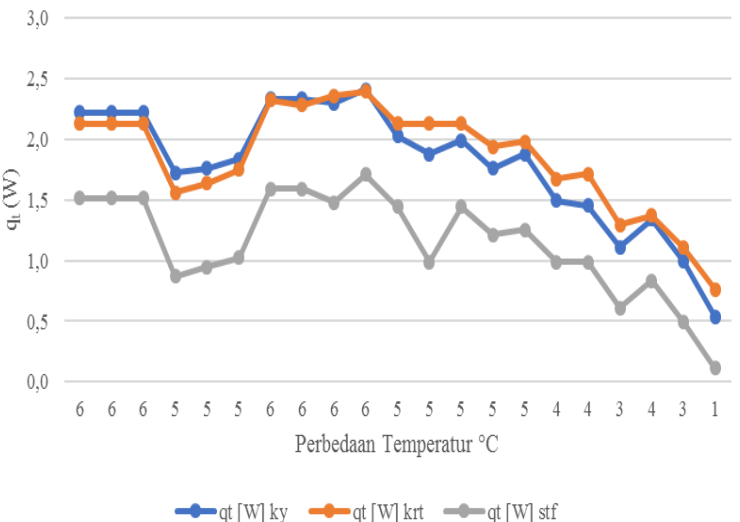

Gambar 4-5 Perpindahan panas tiga material isolator

Dari grafik pada Gambar 4-5 dapat dijelaskan bahwa aliran kalor secara berturut-turut dengan susunan seri melalui kaca, aluminium serta material isolator dan thermoelectric disusun secara pararel. Perpindahan panas konduksi terjadi pada semua material tersebut dan thermoelectric. Dari ketiga material isolator, yang memiliki laju aliran kalor paling tinggi adalah kayu kemudian lebih rendah karet dan paling rendah styrofoam. 
Menurut persamaan (3) laju aliran kalor berbanding lurus dengan konduktivitas. Hal ini ditunjukan pada grafik diatas tampak semakin tinggi nilai konduktivitas termal material maka semakin tinggi perpindahan panas yang terjadi.

\subsubsection{Daya Keluaran Thermoelectric}

Untuk mengetahui korelasi sifat konduktivitas material isolator terhadap daya keluaran thermoelectric maka dibuat keterkaitan perpindahan panas yang terjadi dengan perbedaan temperatur sisi thermoelectric yang menghasilkan daya keluaran.

Tabel 4-9 Hasil perhitungan daya keluaran

\begin{tabular}{|c|c|c|c|c|c|c|c|c|c|c|c|c|c|c|c|}
\hline \multicolumn{6}{|c|}{ Kays } & \multicolumn{5}{|c|}{ Karet } & \multicolumn{5}{|c|}{ Styrofoum } \\
\hline No & $\mathrm{T3}\left[\mathrm{F}^{\circ} \mathrm{C}\right]$ & $\mathrm{TH} \mathrm{[}^{\mathrm{C} \mathrm{C}]}$ & $\mathrm{dt}[\mathrm{W}] \mathrm{kg}$ & $\Delta T^{\circ} \mathrm{K}$ TEKY & P & $\mathrm{T} 3[\mathrm{C} C]$ & $\mathrm{TA}[\mathrm{[C}]$ & qt [i] $\mathrm{ket}$ & $\Delta \mathrm{T} T \mathrm{~K}$ TE Krt & $\mathrm{P}$ & TS[C] & $\mathrm{TH}\left[^{\mathrm{C}} \mathrm{C}\right]$ & $q[\mathbb{W}]$ st & $\Delta T^{\top} K$ IEB Btf & $\mathrm{P}$ \\
\hline 1 & 35,2 & 27,6 & 2.2 & 7,6 & 0,0001 & \begin{tabular}{|l|}
28,2 \\
\end{tabular} & 26,5 & 2,1 & 1,7 & 0,0002 & 34,5 & 26,9 & 1,5 & 7,6 & 0,0002 \\
\hline 2 & 35,3 & \begin{tabular}{|l|}
27,7 \\
\end{tabular} & 2.2 & 7,6 & \begin{tabular}{|l|l|}
0,0022 \\
\end{tabular} & \begin{tabular}{|l|}
28,3 \\
\end{tabular} & 26,6 & 2,1 & 1,7 & 0,0003 & \begin{tabular}{|l|}
34,5 \\
\end{tabular} & 27 & 1.5 & 7,6 & 0,0003 \\
\hline 3 & 35,4 & \begin{tabular}{|l|}
27,8 \\
\end{tabular} & 2,2 & 7,6 & \begin{tabular}{|l|}
0,0003 \\
\end{tabular} & 28,4 & 26,7 & 2,1 & 1,7 & 0,0004 & \begin{tabular}{|l|}
34,7 \\
\end{tabular} & 27,1 & 1,5 & 7,6 & 0,0004 \\
\hline 4 & 34,9 & 28,6 & 1,7 & 6,3 & \begin{tabular}{|l|}
0,0003 \\
\end{tabular} & \begin{tabular}{|l|}
28,6 \\
\end{tabular} & 27,6 & 1.6 & 1 & 0,0004 & \begin{tabular}{|l|}
37,3 \\
\end{tabular} & 27,9 & 0.9 & 9,4 & 0,0004 \\
\hline 5 & 35,8 & 29,7 & 1,8 & 6,1 & 0,0003 & 29,7 & \begin{tabular}{|l|}
28,7 \\
\end{tabular} & 1,6 & 1 & 0,0004 & \begin{tabular}{|l|}
36,7 \\
\end{tabular} & 28,9 & 0.9 & 7,8 & 0,0005 \\
\hline 6 & 36,8 & 30,9 & 1,8 & 5.9 & 0,0003 & 30,8 & 29,7 & 1.7 & 1,1 & 0,0004 & \begin{tabular}{|l|}
38,3 \\
\end{tabular} & 29,9 & 1 & 8.4 & 0,0005 \\
\hline 7 & 36,1 & 29,9 & 2.3 & 6,2 & 0,0004 & 288,6 & 28,3 & 2.3 & 0,3 & 0,0005 & 35,3 & 28,5 & 1,6 & 6,8 & 0,0006 \\
\hline 8 & 35,7 & \begin{tabular}{|l|}
30,2 \\
\end{tabular} & 2,3 & 5,5 & 0,0004 & \begin{tabular}{|l|}
31,3 \\
\end{tabular} & \begin{tabular}{|l|}
28,5 \\
\end{tabular} & 2,3 & 2,7 & 0,0004 & 36,1 & 28,8 & 1,6 & 7,3 & 0,0006 \\
\hline 9 & 36.5 & \begin{tabular}{|l|}
31,2 \\
\end{tabular} & 2,3 & 5,3 & \begin{tabular}{|l|}
0,0004 \\
\end{tabular} & 31 & 29.5 & 2,4 & 1,5 & 0,0005 & 41,5 & 29,9 & 1,5 & 11,6 & 0,0006 \\
\hline 10 & \begin{tabular}{|l|}
35,7 \\
\end{tabular} & 30,2 & 2,4 & 5,5 & \begin{tabular}{|l|}
0,0004 \\
\end{tabular} & \begin{tabular}{|l|}
29,8 \\
\end{tabular} & \begin{tabular}{|l|}
28,4 \\
\end{tabular} & 2,4 & 1,4 & 0,0005 & 36,1 & 28,7 & 1,7 & 7,4 & 0,0006 \\
\hline 11. & 35,5 & 30.6 & 2 & 4,9 & 0,0003 & 29.9 & 28,5 & 2,1 & 1,3 & 0,0005 & \begin{tabular}{|l|}
38,8 \\
\end{tabular} & 29 & 1,4 & 9,8 & 0,0005 \\
\hline 12 & 36,5 & \begin{tabular}{|l|}
31,6 \\
\end{tabular} & 1,9 & 4,9 & 0,0003 & \begin{tabular}{|l|}
30,8 \\
\end{tabular} & \begin{tabular}{|l|}
29,6 \\
\end{tabular} & 3,1 & 1,2 & 0,0004 & 38,1 & 29.9 & 1 & 8,2 & 0,0005 \\
\hline 13 & 35 & 30.1 & 2 & 4,9 & 0,0003 & 29.2 & 28.1 & 2,1 & 1,1 & 0,0004 & 41.6 & 28.5 & 1,4 & 13,1 & 0,0005 \\
\hline 14 & 35,7 & 30,9 & 1,8 & 4,8 & \begin{tabular}{|l|}
0,0003 \\
\end{tabular} & \begin{tabular}{|l|}
30,1 \\
\end{tabular} & 289 & 1,9 & 1,2 & 0,0004 & 40,9 & 29,4 & 1,2 & 11,5 & 0,0005 \\
\hline 15 & 34,8 & 29,7 & 1,9 & 5,1 & \begin{tabular}{|l|}
0,0003 \\
\end{tabular} & \begin{tabular}{|l|}
29,1 \\
\end{tabular} & 28 & 2 & 1,1 & 0,0004 & 4. & 28,4 & 1,3 & 12,6 & 0,0005 \\
\hline 16 & 35,4 & 30,7 & 1.5 & 4,7 & 0,0003 & 29.9 & \begin{tabular}{|l|}
28.8 \\
\end{tabular} & 1,7 & 1,1 & 0,0004 & 38,5 & 29,3 & 1 & 9,2 & 0,0005 \\
\hline 17 & 34,7 & 30 & 1,5 & 4,7 & 0,0003 & \begin{tabular}{|l|}
29,1 \\
\end{tabular} & 28 & 1.7 & 1,1 & 0,0004 & 37,2 & 28,5 & 1 & 8,7 & 0,0005 \\
\hline 18 & 35 & \begin{tabular}{|l|}
30,3 \\
\end{tabular} & 1,1 & 4,7 & \begin{tabular}{|l|}
0,0002 \\
\end{tabular} & 29,5 & \begin{tabular}{|l|}
28,5 \\
\end{tabular} & 1,3 & 0,9 & 0,0003 & \begin{tabular}{|l|}
35,8 \\
\end{tabular} & 29,2 & 0,6 & 6,6 & 0,0004 \\
\hline 19 & 33,8 & 29 & 1,3 & 4,8 & 0,0002 & \begin{tabular}{|l|}
28,3 \\
\end{tabular} & 27,4 & 1,4 & 0,9 & 0,0003 & 40,1 & 27,8 & 0,8 & 12,3 & 0,0004 \\
\hline 20 & 33,2 & 28,7 & 1 & 4,5 & 0,0002 & 27,8 & 27,1 & 1,1 & 0,7 & 0,0002 & 39 & 27,6 & 0,5 & 11,4 & 0,0003 \\
\hline 21 & 39,5 & \begin{tabular}{|l|}
29,4 \\
\end{tabular} & 0,5 & 4,1 & \begin{tabular}{|l|l|}
0,0001 \\
\end{tabular} & 28,5 & \begin{tabular}{|l|}
27,8 \\
\end{tabular} & 0,8 & 0,7 & 0,0001 & 39 & 28,3 & 0,1 & 10,7 & 0,0002 \\
\hline
\end{tabular}

Agar lebih mudah dalam menjelaskanya, diperlihatkan pada grafik dibawah.

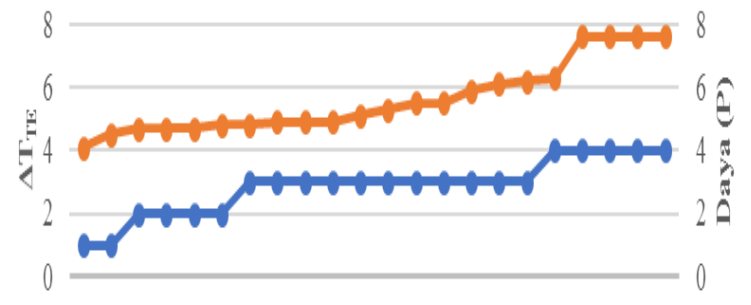

111122222222222222222

$q_{t}(\mathrm{~W})$

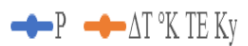

Gambar 4-6 Pengaruh penggunaan isolator kayu

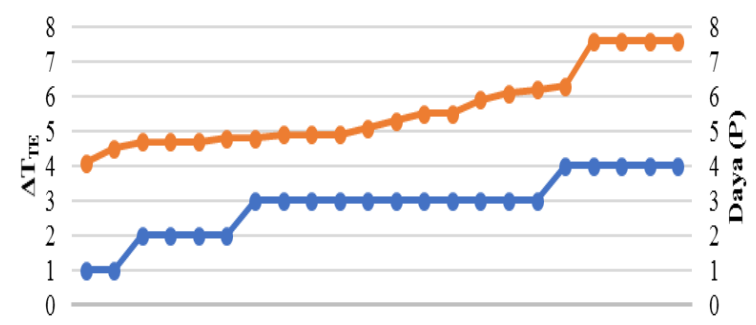

11111222222222222222222222222

$q_{t}(W)$

$\rightarrow-\mathrm{P} \diamond \Delta \mathrm{T} \% \mathrm{~K}$ TE Krt

Gambar 4-7 Pengaruh penggunaan isolator karet

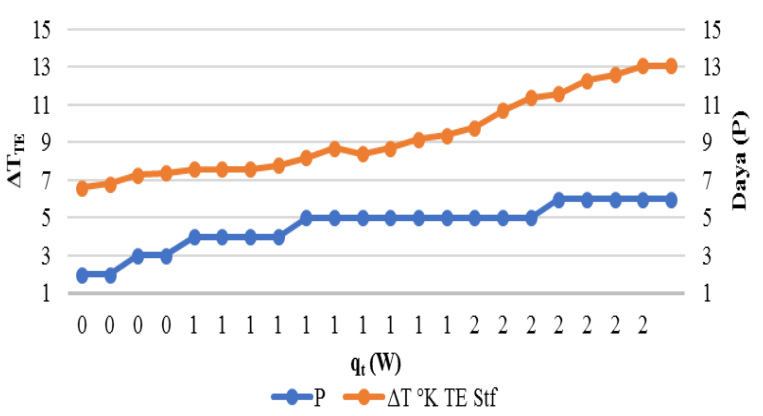

Gambar 4-8 Pengaruh penggunaan isolator styrofoam

Pengaruh daya keluaran untuk ketiga isolator pada sistem thermoelectric, dibandingkan satu sama lain menggunakan grafik berikut.

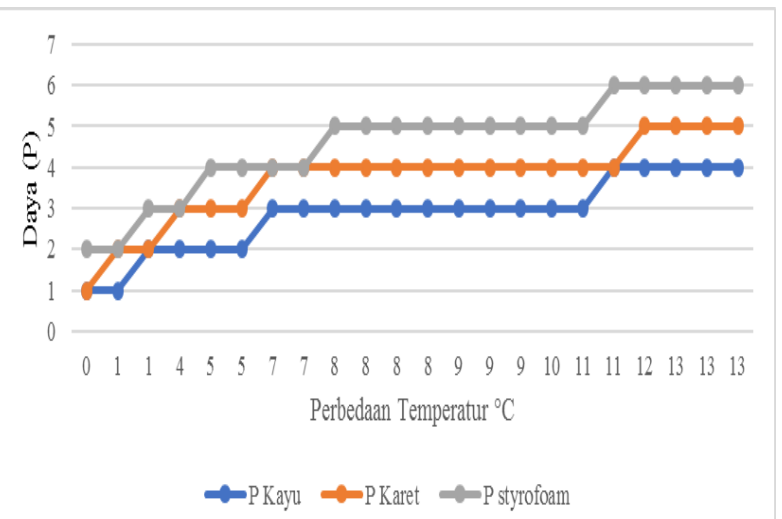

Gambar 4-9 Pengaruh penggunaan isolator terhadap daya keluaran

Setelah melihat grafik diatas dapat jelaskan bahwa styrofoam menghasilkan daya paling tinggi dibandingkan dengan karet dan kayu. Berbanding terbalik dengan perpindahan panas pada styrofoam, dimana styrofoam menghasilkan perpindahan panas yang rendah. Artinya untuk menghasilkan daya keluaran yang tinggi tidak dipengaruhi oleh perpindahan panas, melaikan dipengaruhi oleh perbedaan temperatur thermoelectric.

\section{BAB 5 SIMPULAN}

\subsection{Simpulan}

Penelitian thermoelectric yang menggunakan material isolator kayu, karet dan styrofoam menghasilkan kesimpulan:

1. Material isolator kayu, karet, styrofoam berpengaruh terhadap perpindahan panas pada sistem thermoelectric yang ditandai dengan nilai konduktivitas termal pada setiap isolator.

2. Daya keluaran generator thermoelectric dengan isolator berbahan styrofoam memiliki perpindahan panas yang rendah dan daya keluaran yang lebih tinggi dibandingkan dengan material isolator lain.

\section{DAFTAR KEPUSTAKAAN}

Aby Elsa Putra, Rifky, A. F. (2018). Pemanfaatan Panas Buang Atap Seng dengan Menggunakan Generator Termoelektrik sebagai Sumber Energi Listrik Terbarukan, 3(2502), 3843.

Afdhal Kurniawan Mainil. (2012). Kaji Eksperimental Aalat Uji Konduktivitas Termal Bahan, 241-248. 
Al-Fikri, H. A. (2016). Efektifitas Modul Peltier Tec-12706 Sebagai Generator Dengan Memanfaatkan Energi Panas Dari Modul PeltierTec-12706.UniversitasMuhammadiyah Surakarta.

Aby Elsa Putra, Rifky, A. F. (2018). Pemanfaatan Panas Buang Atap Seng dengan Menggunakan Generator Termoelektrik sebagai Sumber Energi Listrik Terbarukan, 3(2502), 3843.

Afdhal Kurniawan Mainil. (2012). Kaji Eksperimental Aalat Uji Konduktivitas Termal Bahan, 241-248.

Al-Fikri, H. A. (2016). Efektifitas Modul Peltier Tec-12706 Sebagai Generator Dengan Memanfaatkan Energi Panas Dari Modul Peltier Tec-12706. Universitas Muhammadiyah Surakarta.

Ali, M., \& Kurniawan, R. (2013). Kaji Eksprimental Konduktivitas Termal Isolator Dari Serbuk Batang Kelapa Sawit, 1, 59-68.

Amurulah. (2013). Uji eksperimental kinerja termoelektrik pada pendingin dispenser air minum.

Belessiotis, Vassilis, Soteris Kalogirou, E. D. (n.d.). Thermal Solat Desalination.

Dany Santoso, Wanda K., \& A. J. (2013). Efektivitas Styrofoam Sebagai isolator Panas Pada Atap Miring Di Surabaya. LAporan Penelitian, 1-29.

Firmansyah Burlian, M. I. K. (2014). Permukaan Variasi Ketebalan Isolator Terhadap Laju Kalor Dan Penurunan Temperatur Pada Permukaan Dinding Tungku Biomassa, (November), 26-27.

Goleman, Daniel; Boyatzis, Richard; Mckee, A. (2019). Kajian Konduktivitas Panas Berbagai Jenis Kayu Sebagai Bahan Isolator. Journal of Chemical Information and Modeling, 53(9), 1689-1699. https://doi.org/10.1017/CBO9781107415324.004

Hamdi_2017. (n.d.). Pengaruh Konduktivitas Panas Material Pada Laju Penguapan Air Laut Dengan Pemanasan Matahari.
Hariady, S., \& Fauzie, M. A. (2014). Kaji Eksperimental Kemampuan Daya Hantar Kalor Campuran Styrofoam , Kulit Jengkol Dan Semen Sebagai Alternatif Bahan Isolator, 2(2), 119-130.

J.P Holman. (2010). Heat Transfer.

Mohammad Istajarul Alim, Dina Mardiana, Anita Dwi A, D. A. (2017). Uji Konduktivitas Termal Material Non Logam.

Pepayosa, F. (2018). Rancang Bangun Kotak Pendingin Peltier Penyimpanan Buah dan Sayur dengan Sumber Tenaga Surya.

Rui, J., \& de Oliveir, M. C. C. (2011). Principles of Direct Thermoelectric Conversion. Heat Analysis and Thermodynamic Effects. https://doi.org/10.5772/20619

Sabin. (2017). Jurnal skripsi "Pengaruh Sudut Antara Dua Panel Berbentuk Profil V terhadap Penyerapan Radiasi Matahari pada Panel Surya".

Sari, I. R. J., \& Fatkhurahman, J. A. (2015). Review of Determining Dry Rubber Content on Processing Rubber Sheet. Prosiding Seminar Nasional Kulit, Karet Dan Plastik, 169-180.

Sugiyanto, H., Paronda, A. H., \& Samsiana, S. (2015). Rancang Bangu Pemanfaatan Thermoelectric Sebagai Pendingi Pada Kontrol Injection Plastik, 5(2), 125-138.

Sulistiyawati Dewi K., Dina Mardiana, Anita Dwi A., Z. (2014). Uji Konduktivitas Termal dengan Pyrometer pada Kayu, Karet, dan Arang, 2-5.

Wibowo, H. (2008). Studi Banding Konduktifitas Panas Antara Gabus (Styrofoam) dengan Sekam Padi, 112-118.

Zhou, D., \& Chu-ping, S. (2015). Research Article Study on thermoelectric material and thermoelectric generator, 7(3), 395401 .

Note: Penulisan pustaka menggunakan Mendeley atau EndNote dengan APA style 7 edition. 